\title{
EFFECT OF AGE AND EDUCATION LEVEL ON OPERATOR'S PERFOMANCE WITH HARVESTER VIRTUAL REALITY SIMULATOR
}

\author{
Eduardo da Silva Lopes ${ }^{1 *}$, Millana Burger Pagnussat ${ }^{2}$, Oscar Manuel de Jesús Vera Cabral ${ }^{3}$ \\ 1*Department of Forestry Engineering, Midwestern Parana State University, Irati, Parana, Brazil - eslopes@ unicentro.br; \\ ${ }^{2}$ Midwestern Parana State University, Post-Graduation Program in Forestry Sciences, Irati, Parana, Brazil - \\ millanap@gmail.com; ${ }^{3}$ National University of Assunção, Paraguai - oscarveracabral@gmail.com
}

Received for publication: 01/02/2017 - Accepted for publication: 05/06/2018

\begin{abstract}
The aim of this study was to analyze the effect of age and education level on performance of forest operators during the training with the harvester virtual reality simulator (HVRS). The study was performed in the Forest Operator Training Centre (CENFOR), of the Midwestern State University (UNICENTRO), located in the municipality of Irati, state of Paraná, Brazil. Data of 124 professionals trained in the HVRS were used. A specialized software was used to simulate machine operation, and operational performance was conducted with the operators at the start and at the end of two operating modules. Results indicated that younger individuals had a better performance for the studied variables, as they could better assimilate the techniques and developed faster. This result shows that age is an important element to identify the ideal profile of people to be recruited as future harvester operators.

Keywords: Profile, training, productivity.
\end{abstract}

\section{Resumo}

Efeito da idade e nível de educação na performance de operários em um Simuladores de Realidade Virtual Harvester. Objetivou-se neste trabalho analisar o efeito da idade e do nível de escolaridade no desempenho de operadores durante o treinamento com uso de Simuladores de Realidade Virtual Harvester (HVRS). O estudo foi desenvolvido no Centro de Formação de Operadores Florestais (CENFOR), da Universidade Estadual do Centro-Oeste (UNICENTRO), localizada no município de Irati (PR). Foram usados dados de 124 operadores que receberam treinamento de formação em HVRS. Foi empregado um software especializado para a simulação da operação da máquina e foram coletadas as médias de desempenho das variáveis operacionais no início e final dos módulos do simulador. Os resultados indicaram que as pessoas mais jovens obtiveram melhor desempenho nas variáveis operacionais estudadas, assimilando melhor as técnicas transmitidas e demostrando, ainda, que a variável idade é um elemento importante na identificação do perfil ideal das pessoas a serem recrutadas como futuros operadores de Harvester.

Palavras-Chave: Perfil, treinamento, produtividade.

\section{INTRODUCTION}

The process of technological innovation on timber harvester started to be more prominently in Brazil since the 1990s, as the Brazilian market opened to imports of machinery and equipment. However, in addition to the available technology, high productivity, best ergonomic, and safety conditions at work, timber harvesting machines demand a high complexity of operations, high operating costs, and highly skilled workers.

Lopes et al. (2010), Purfürst (2010) and Lopes and Pagnussat (2017) state that the main challenge on the efficient use of forest machines is the training of workers, especially in places where the technology was recently incorporated and no trained operators are available. As human resources are an integral part of the development of new technologies, training forest machine operators is believed to be the main source of improvement and innovation in the production processes.

Lapointe and Robert (2000) indicate that the systematic and planned training of operators is the most important issue since the introduction of the high technological machines. Considering this incorporation of measures, which aims at the adaptation and technological evolution of machines and the improvement of labor standards in forestry, Pagnussat and Lopes (2017) state that some of the reasons for the increasing importance of training are the intensifying competition, technological changes and pursuit for productivity gains that increase the qualification requirements of the operator. Therefore, training aims to improve the professional development of human being on the performance of their duties, as well as to develop and improve skills and knowledge of employees on organizations.

FLORESTA, Curitiba, PR, v. 48, n. 4, p. 463-470, out/dez. 2018

Lopes. E.D. et al.

ISSN eletrônico 1982-4688

DOI: $10.5380 /$ rf.v48i4.50437 
However, it is difficult to identify people who have potential to be trained for the role of forest machine operators. Large financial resources are often invested in the training of operators who do not have such capacity, causing low productivity, accident risks, and high costs. Lopes and Pagnussat (2017) notice that being able to identify people with the suitable profile and potential to be trained as a forest machine operator is essential in order to have an efficient selection process. It is also important that the selected person presents a set of special requirements, such as motor skills, attention, spatial orientation, and visual memory, which alongside the training method can result in a skilled operator, able to successfully run the machine. The ability to adapt and learn originates from the nervous system functions as a response to experience. However, this development depends on internal processes determined by an individual capacity, which varies with age, part of the body to be developed, physical capacity, among others factors (SCHMIDT; RISBERG, 2008).

In this regard, virtual reality simulators of forest machines were introduced to support training programs and offer effective training to operators by providing the acquisition of skills to handle the machine in similar conditions to those of forests. Thus, they create working methods and skills and plan actions to be implemented in forest operations. In addition, virtual reality simulators promote repetition, possibility of control by the facilitator, and implementation of a logical plan and flexible situations, aiming to ensure that the combination of man and machine can achieve the highest levels of competitiveness in forest production (GELLERSTEDT, 2002).

According to Lopes et al. (2008), virtual reality simulators are high performance training tools, which allow the training of operators in a shorter period of time and lower cost. They are also critical for their high technological level and operational costs of machinery, which does not technically and economically allow trainings only in real field situations.

Therefore, this research began from the hypothesis that age and education level can influence the performance of forest machine operators. Thus, this study aimed to determine if the age and education level of forest machine operators cause performance variations during the training period. Moreover, through the harvester virtual reality simulator, it aimed to identify factors that could help to define the ideal profile of candidates to be trained for this work, improving the people recruitment and training process.

\section{MATERIALS AND METHODS}

This research was carried out at the Forest Operators Training Center (CENFOR) of the Midwestern State University (UNICENTRO), located in the municipality of Irati, state of Paraná, Brazil. The study was based on a sample of 124 workers from several Brazilian forestry companies, who had no experience in forests machines and received initial training on harvester virtual reality simulator (HVRS) for 40 hours, during the period from 2006 to 2011 . The operators were trained on virtual reality simulators developed by Simlog Simulation Launcher. The harvester simulation program was set on computers equipped with joysticks, similar to those used in forest machines (Figure 1).

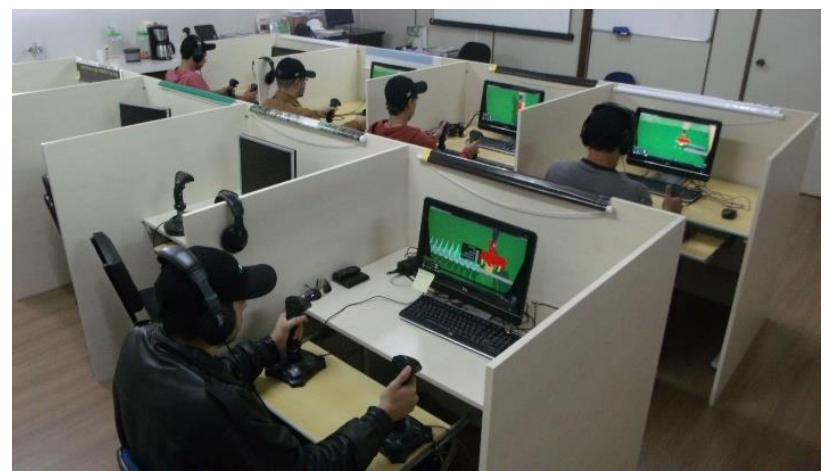

Figure 1. Harvester operators trained on virtual reality simulators.

Figura 1. Treinamento de operadores de Harvester no simulador de realidade virtual

The training program consisted of seven operating modules: Module 1 -commands on joysticks for 2 hours; Module 2 -control of movements for 6 hours; Module 3 -single-tree harvesting for 8 hours; Module 4 - single-tree harvesting and logging for 6 hours; Module 5 - simple processing and stacking for 6 hours; Module 6 - multiple stacking and logging for 4 hours; and Module 7 - processing for 8 hours.

Modules 3 and 6 were considered to be the most relevant ones, since they comprise all harvest operations as in a real action. These modules were renamed as Operating Module I and Operating Module II, respectively. In order to support the selection of operating variables for the analysis, the study by Lopes et al. (2008) was considered. 
The relevant variables at each operating module were: Execution time - time needed to perform the operations (Modules I and II); Stump height $(\mathrm{cm})$ - cutting height of trees in relation to the desired height (Modules I and II); Stacking efficiency (\%) - percentage of logs correctly stacked (Module II); Productivity $\left(\mathrm{m}^{3} /\right.$ hour $)$ - effective amount of product obtained per unit of time during the operation (Module II).

Operators were grouped into five age classes: 1) 26 operators from 18 to 22 years-old; 2) 45 operators from 23 to 27 years-old; 3) 32 operators from 28 to 32 years-old; 4) 10 operators from 33 to 37 years-old; and 5) 11 operators with 37 years-old or more. The same sample was divided into four education levels: 1) 19 operators with incomplete primary education; 2) 13 operators with full primary education; 3) 14 operators with incomplete secondary education; and 4) 78 operators with complete high school.

Data regarding the performance of the operators were obtained from two different training periods based on the average of ten simulations at the start and end of each operating module. It is also important to note that a performance goal was established for each variable before training, according to historical training data.

To assess the performance gain achieved by operators during training, we used the following equation (Equation 1):

$$
\mathrm{g}(\%)=\left(1-\left(\frac{\mathrm{m} 2}{\mathrm{~m} 1}\right)\right) \times 100
$$

In which: $g(\%)$ : performance gain compared to the start of training, for each variable and module; $\mathrm{m}_{2}$ : average at the end of the module; and $\mathrm{m}_{1}$ : average at the start of the module.

Data regarding the performance of the operators at the start and at the end of each module for each variable were compared by a "t paired" test at $5 \%$ level of significance. We considered a completely randomized design, and the average performances of the operators were compared by Tukey's test at $95 \%$ probability, aiming to determine whether there was statistical difference among operators of different age classes and education levels or not.

\section{RESULTS}

\section{Execution time}

Execution time represents the time needed by operators to perform the tasks of Modules I and II, according to their age classes and education levels (Figure 2).
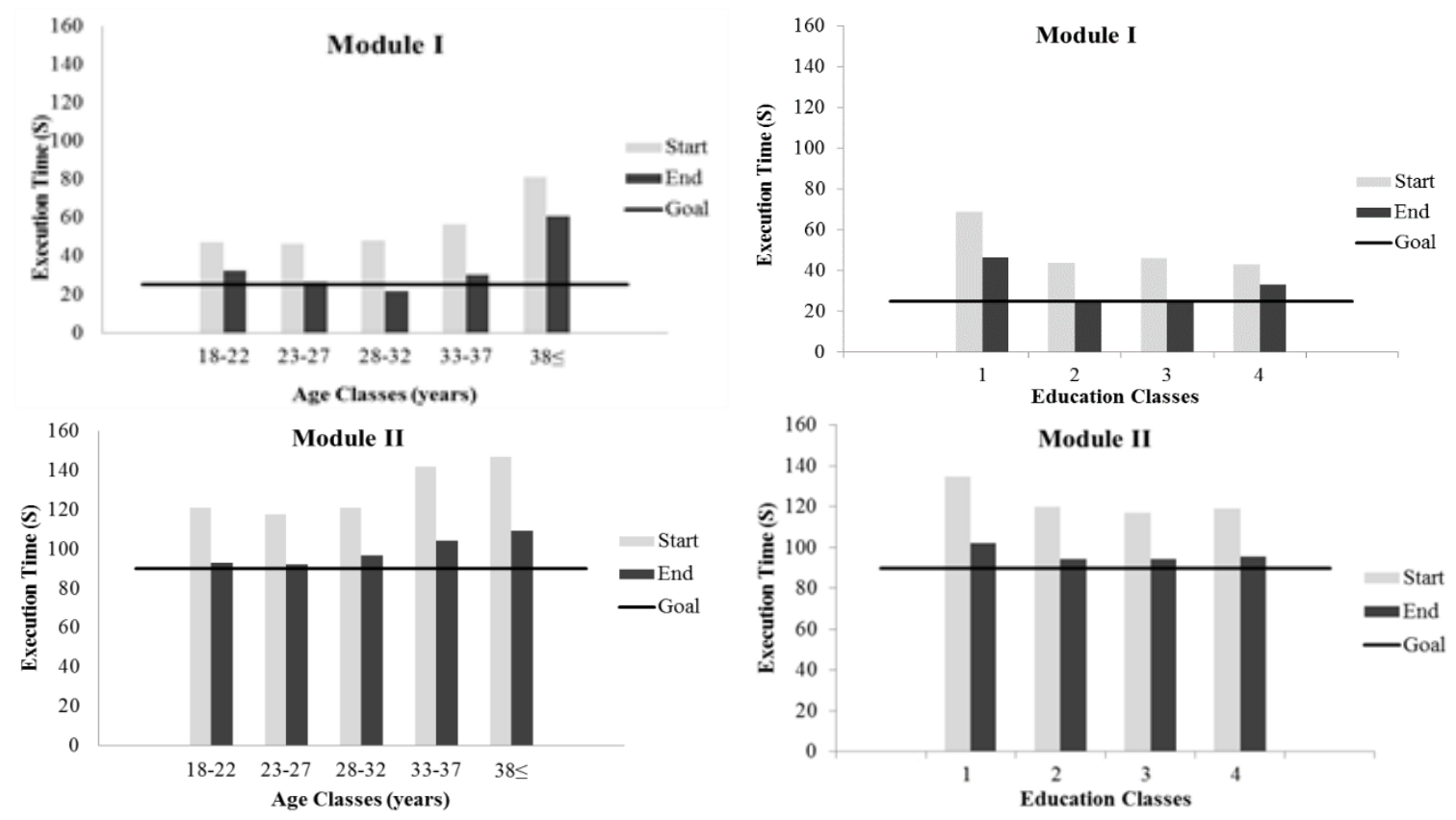

Figure 2. Average execution time of operators from different age classes and education levels for Modules I and II. Figura 2. Tempo médio de execução dos operadores de diferentes idades e níveis de escolaridade no Módulo I e II. 
The execution time for Modules I and II indicates a tendency that older operators take longer to perform the operation. This variable has a straightforward effect on productivity. Younger operators did not decrease the run-time below the average. With regards to the education level 4 , the goal was not achieved even with a lower initial execution time when compared to the other classes.

\section{Stump height}

The characteristics of the product and relief of the harvested area mostly influence stump height. Figure 3 shows the performance achieved by operators from different age classes and education levels during training.
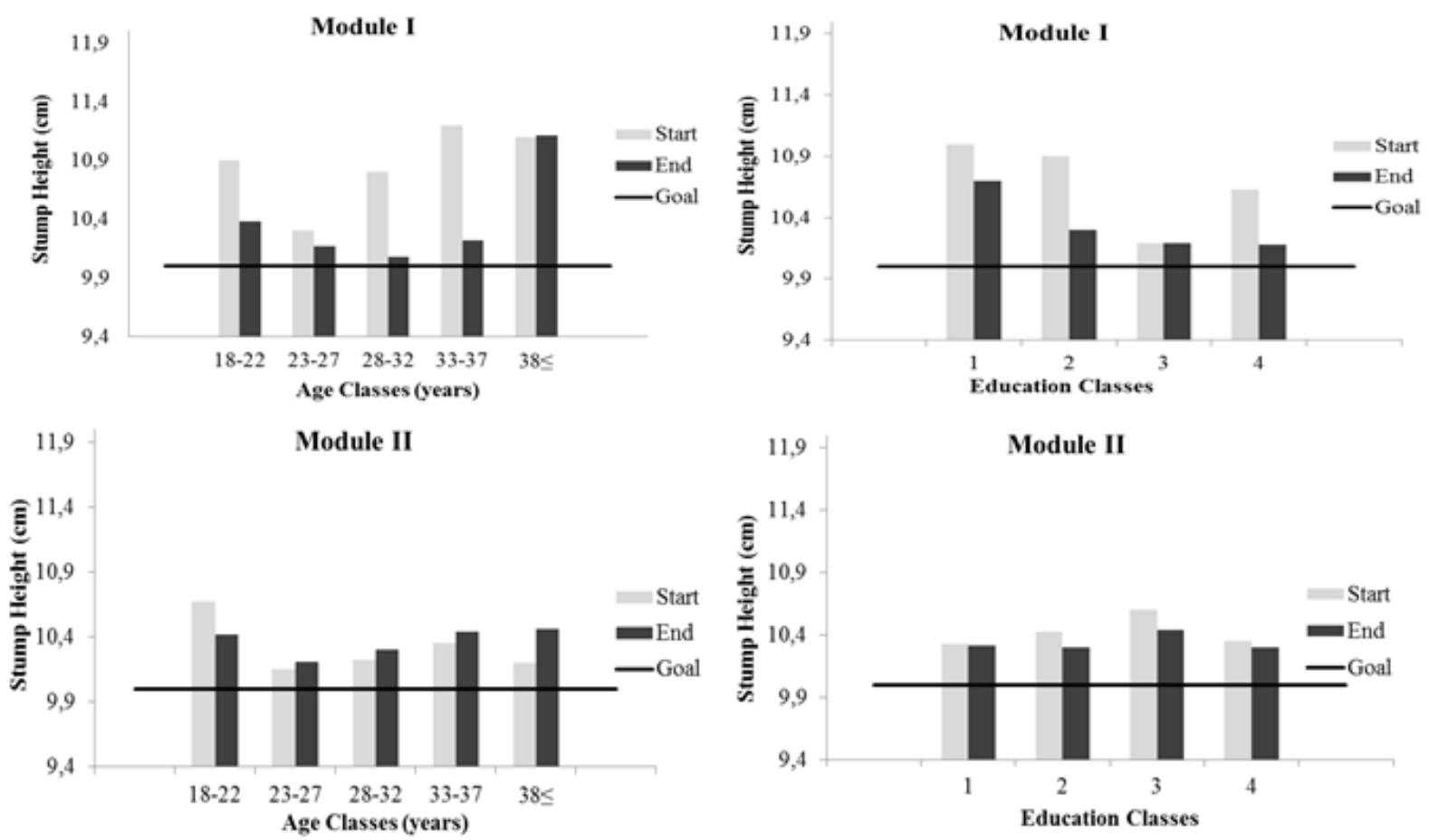

Figure 3. Average performance of operators from different age classes and education levels regarding stump height for Modules I and II.

Figura 3. Desempenho dos operadores de diferentes idades e níveis de educação em relação à altura do toco nos Módulos I e II.

Operators improved their abilities for Module I when the results at the start and at the end of training are compared. However, by analyzing age classes from 23 to 38 years-old (and above) for Module II, an opposite tendency can be observed, possibly because this module comprises the complete forest operation, i.e., operators are required to work with many trees and increased difficulty. Thus, older age classes presented more difficulty on operating performance, except for the age class from 18 to 22 years-old, in which the younger operators could be regarded as more capable.

\section{Stacking efficiency}

Stacking efficiency represents the ability of the operator on controlling the machine to leave logs in appropriate places at the end of the operation. This task is very important in forest harvesting, since it indicates the overall quality of the whole process. Figure 4 shows the result on the average performance of operators from different age classes and education levels during the training of the HVRS. 

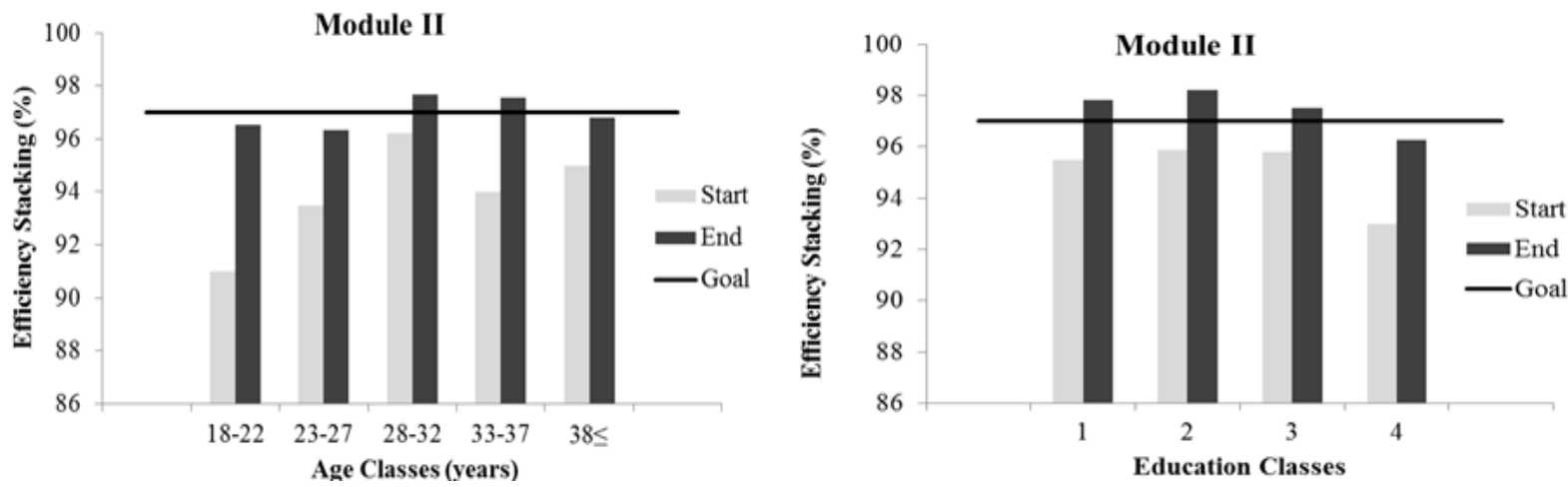

Figure 4. Average performance of the operator from different age classes and education levels regarding the stacking efficiency for Module II.

Figura 4. Desempenho médio dos operadores de diferentes idades e níveis de escolaridades em relação à eficiência de empilhamento do Módulo II.

Operators from all age classes improved their performance, presenting a significant difference between the start and the end of training ( $\mathrm{p}<0.05$ ). Operators from 28 to 37 years presented the highest performance gain, even exceeding the performance goal established. By analyzing the performance of operators according to education levels, a positive tendency was detected as a significant difference between the start and the end of training $(\mathrm{p}<0.05)$ could be observed.

\section{Productivity}

Productivity comprises most of the other variables. The average productivity obtained by operators from different age classes and educational levels during the training of the HVRS in presented in Figure 5.
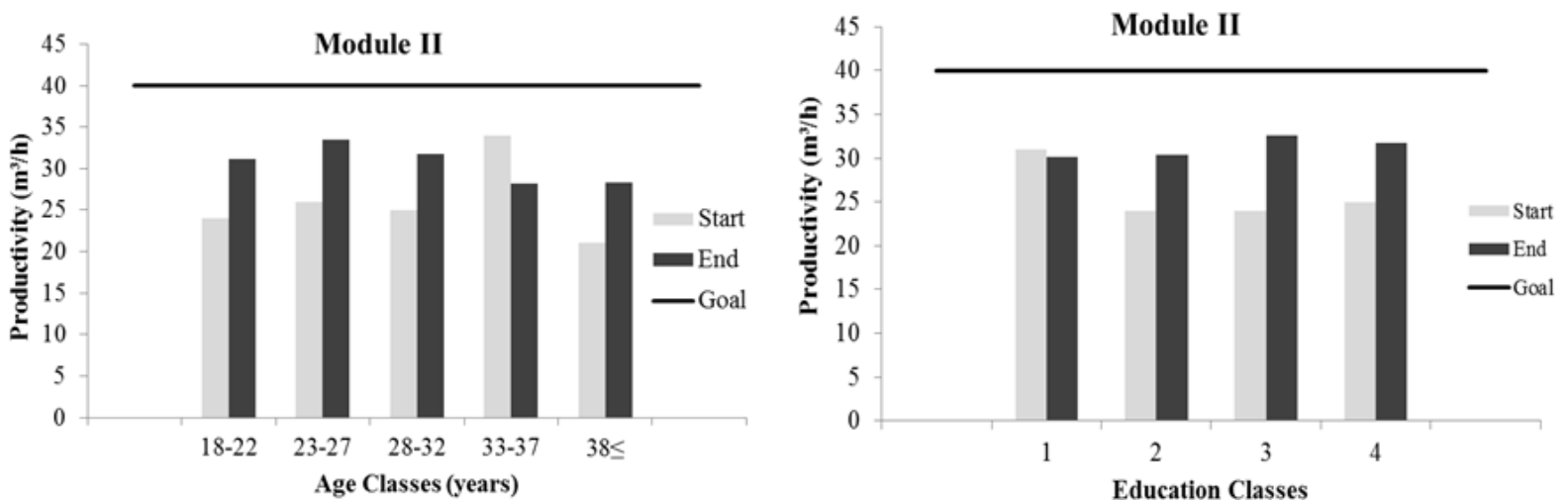

Figure 5. Performance of operators from different age classes and education levels regarding the productivity for Module II.

Figura 5. Desempenho dos operadores de diferentes idades e níveis de escolaridade em relação à produtividade no Módulo II.

Regarding age classes, younger operators achieved better performances. However, education level did not significantly affect the productivity. Both age classes and education levels showed significant improvement between the start and the end of training ( $p<0.05)$, even though operators with lower education levels presented similar productivity results for both evaluations. Moreover, in both situations, operators did not achieve the productivity goal of $40 \mathrm{~m}^{3} / \mathrm{h}$, which would require more experience to be achieved.

Table 1 displays the result of Tukey's test at $95 \%$ of probability for the average performance regarding variables from Module I. 
Table 1. Results of Tukey's test at $95 \%$ of probability for the operating variables analyzed from Operational Module I. Tabela 1. Resultados do teste de Tukey a 95\% de probabilidade para o Módulo Operacional I.

\begin{tabular}{cccc}
\hline \multicolumn{1}{c}{ Operators groups } & Execution time & Stump height \\
$(\mathbf{s})$ & $32.11 \mathrm{ab} *$ & $10.38 \mathrm{a}$ \\
& $18-22$ & $26.39 \mathrm{ab}$ & $10.17 \mathrm{a}$ \\
& $23-27$ & $21.69 \mathrm{~b}$ & $10.08 \mathrm{a}$ \\
Age Classes (years) & $28-32$ & $30.26 \mathrm{ab}$ & $10.22 \mathrm{a}$ \\
& $33-37$ & $60.66 \mathrm{a}$ & $11.11 \mathrm{a}$ \\
\hline \multirow{2}{*}{ Education levels } & $38 \leq$ & $46.41 \mathrm{a}$ & $10.70 \mathrm{a}$ \\
& 1 & $25.50 \mathrm{a}$ & $10.30 \mathrm{a}$ \\
& 3 & $25.82 \mathrm{a}$ & $10.19 \mathrm{a}$ \\
\hline
\end{tabular}

*Means followed by the same letter do not differ statistically by Tukey's test at $95 \%$ of probability.

Results indicate similarity on the performance of operators from all the education levels, considering both variables from Module 1. These numbers could result from the simplicity of operational tasks from Module 1.

Table 2 shows the result of Tukey's test at $95 \%$ of probability for average performance of operators considering variables from Module II.

Table 2. Results of Tukey's test at $95 \%$ of probability for operating variables analyzed from Operational Module II. Tabela 2. Resultados do teste de Tukey a 95\% de probabilidade para o Módulo Operacional II.

\begin{tabular}{|c|c|c|c|c|c|}
\hline \multicolumn{2}{|c|}{ Operator/Classes } & \multirow{2}{*}{$\begin{array}{c}\begin{array}{c}\text { Execution time } \\
(\mathbf{s})\end{array} \\
93.07 \mathrm{a}^{*}\end{array}$} & \multirow{2}{*}{$\begin{array}{c}\begin{array}{c}\text { Stump height } \\
\text { (cm) }\end{array} \\
10.42 \mathrm{a}\end{array}$} & \multirow{2}{*}{$\begin{array}{c}\begin{array}{c}\text { Stacking } \\
\text { efficiency } \\
(\%)\end{array} \\
96.52 \mathrm{a}\end{array}$} & \multirow{2}{*}{$\begin{array}{c}\begin{array}{c}\text { Productivity } \\
\left(\mathbf{m}^{3} / \mathbf{h}\right)\end{array} \\
31.15 \mathrm{ab}\end{array}$} \\
\hline \multirow{5}{*}{$\begin{array}{l}\text { Age classes } \\
\text { (years) }\end{array}$} & $18-22$ & & & & \\
\hline & $23-27$ & $92.20 \mathrm{a}$ & $10.21 \mathrm{a}$ & $96.34 \mathrm{a}$ & $33.49 \mathrm{a}$ \\
\hline & $28-32$ & $96.62 \mathrm{a}$ & $10.30 \mathrm{a}$ & $97.69 \mathrm{a}$ & $31.82 \mathrm{ab}$ \\
\hline & $33-37$ & $104.31 \mathrm{a}$ & $10.44 \mathrm{a}$ & $97.57 \mathrm{a}$ & $28.21 \mathrm{~b}$ \\
\hline & $38 \leq$ & $109.41 \mathrm{a}$ & $10.46 \mathrm{a}$ & $96.82 \mathrm{a}$ & $28.30 \mathrm{~b}$ \\
\hline \multirow{4}{*}{ Education levels } & 1 & $102.3 \mathrm{a}$ & $10.32 \mathrm{a}$ & $97.84 \mathrm{a}$ & $30.16 \mathrm{a}$ \\
\hline & 2 & $94.22 \mathrm{a}$ & $10.30 \mathrm{a}$ & $98.23 \mathrm{a}$ & $30.43 \mathrm{a}$ \\
\hline & 3 & $94.30 \mathrm{a}$ & $10.44 \mathrm{a}$ & $97.53 \mathrm{a}$ & $32.63 \mathrm{a}$ \\
\hline & 4 & $95.51 \mathrm{a}$ & $10.30 \mathrm{a}$ & $96.27 \mathrm{a}$ & $31.69 \mathrm{a}$ \\
\hline
\end{tabular}

*Means followed by the same letter do not differ statistically by Tukey test at $95 \%$ of probability.

Even though there is a tendency that older operators take longer execution time, there was no statistical difference between the age groups for this variable, nor for stump height and stacking efficiency. However, by analyzing the overall productivity, a tendency that younger operators present better performance can be observed.

\section{DISCUSSION}

Results of the operational training indicate that younger candidates have better conditions or skills to be trained as harvester operators. Their abilities (represented by their performances) show that they were able to better comprehend the lessons, obtaining practice in training with the HVRS methodology. Moreover, the characteristics of younger operators allowed them to develop the motor skills needed to achieve greater effectiveness in the established goals. We also recognize that the learning curves are variable for each individual, mainly due to physical and mental ability, which are aspects of tacit knowledge and are related to age and intellectual development. The age range found by this study as ideal for training corresponds to individuals between 23 and 37 years-old. 
The class of the youngest operators did not achieve the goal, even though it had a standard performance at the beginning of the training. This may have occurred due to the fact that very young people are generally more comfortable in learning movements, but they lack in patience. These results were also observed by Nitrini et al. (2008), as the authors indicate that education was not very significant in the result. They also notice that with regards to age, although the younger individuals obtained better results, the very young or very old individuals did not obtain the best results. Besides, Lopes and Pagnussat (2017) observed that younger people, in spite of learning faster, are also usually less patient and therefore may often become impatient and present unsatisfactory or less satisfactory results during a very repetitive activity, such as simulator training. This factor can be minimized in practical operation, since there are goals and incentives to be achieved.

In addition, according to Seidler et al. (2010), age-related declines in brain structure and neurotransmitter availability lead to greater demand on cognitive resources for compensation. The prefrontal systems, which support such cognitive processes, are the most vulnerable to age-related losses, leading to reduced availability of compensatory mechanisms.

According to Lapointe and Robert (2000), operating timber harvest machines depend on work technique, work habits and customs, and personal skills. The use of the HVRS on training standardizes the costumes of operators, which are usually formed later, while working in the forestry sector. Additionally, it allows the analysis of the performance of the operators. Therefore, since there are other aspects that influence the performance of workers, beyond age and education, such as the profile of the operator, a more in-depth evaluation of people recruitment should be considered.

Ovaskainen et al. (2004), by observing the performance of the operators, especially on productivity, conclude that results may vary up to $40 \%$ among operators that work in similar conditions. Thus, training is also important to improve the individual work techniques, motor skills, mental planning, and training in decision-making as in a real work practice. The development of the motor skills of operators increases as they are trained on the HVRS and achieves its maximum as the operators obtain experience over the years of work.

Age class of candidates may be a previous indication of the performance they can achieve during the training of the HVRS. Although these variables should not be regarded as conclusive proof of the ideal profile of a future operator on forestry equipment, they may serve as requirements for potential recruitment of candidates with motor, sensory and cognitive skills needed for the job. We observed that the younger and older age classes, i.e., the two extremes, obtained the worst performances, as well as the highest-grade class.

The operational modules and variables analyzed comprise different degrees of difficulty that require several abilities from the operators. Thus, training allows them to achieve standard accuracy, especially when integrated timber harvest operations in forests are combine to varying conditions. The complexity of actions needed demands improvement of motor skills, which are regulated by physical capacity along with mental abilities.

The education level did not show any correlation with the performance of operators in the HVRS. However, this result should not be interpreted as if the education was not an important variable for the operator, since they need to fill out reports, interpret machine warning signs, among other situations that managers consider education as a fundamental requirement for the job. However, in order to investigate whether education affects cognitive ability or not, it is necessary to test individuals after they have completed different education levels, using a test that does not favor individuals with specific types of education. Natural candidates in this regard have various types of intelligence (FALCH; MASSIH, 2011).

Training schools should consider the profile of the operator as a previous criterion, since it is desirable that the training method promotes the best results as possible. Results by Silayo et al. (2014) should also be considered as they emphasize that forest machine technologies usually come from developed countries, where machines are operated by individuals with a high level of education, trained in courses with high quality standards. An efficient harvester operator does his work with a high-quality standard and high productivity. Although both aspects have a close relationship, a part of the operating variables analyzed are regarded as parameters that describe the quality of operation of this machine.

\section{CONCLUSIONS}

- The results indicated that younger operators had better performance for most of the studied variables, since they could better assimilate the techniques.

- Education level is not a significant factor that influences in forest machines operations.

- Age of the candidate is an important criterion on the identification of the ideal profile of individuals to be recruited as potential forest machines operators.

- Operators presented significant gains in performance during the training of the HVRS, indicating the importance of simulator on the capacitation of forest operators.

FLORESTA, Curitiba, PR, v. 48, n. 4, p. 463-470, out/dez. 2018

Lopes. E.D. et al.

ISSN eletrônico 1982-4688

DOI: $10.5380 /$ rf.v48i4.50437 


\section{REFERENCES}

FALCH, T.; MASSIH, S. S. The effect of education on cognitive ability. Economic Inquiry, v. 49, n. 3, p.838$856,2011$.

GELLERSTEDT, S. Operation of the single-grip harvester: motor-sensory and cognitive work. International Journal of Forest Engineering, v. 13, n. 2, p. 35-47, 2002.

LAPOINTE, J. F.; ROBERT, J. M. Using VR for efficient training of forestry machine operators. Education and Information Technologies, v. 5, p. 237-250, 2000.

LOPES, E. S.; CRUZINIANI, E.; ARAUJO, A. J.; SILVA, P. C. Avaliação do treinamento de operadores de harvester com uso de simulador de realidade virtual. Revista Árvore, v. 32, n. 2, p. 291-298, 2008.

LOPES, E. S.; OLIVEIRA, D. O.; SILVA, P. C.; CHIQUETTO, A. L. Avaliação do desempenho de operadores no treinamento com simulador virtual forwarder. Ciência Florestal, v. 20, n. 1, p. 177-186, 2010.

LOPES, E. S.; PAGNUSSAT, M. B. Effect of the behavioral profile on operator performance in timber harvesting. International Journal of Forest Engineering, v. 28, p. 1-6, 2017.

NITRINI, R.; BRUCKI, S. M. D.; SMID, J.; CARTHERY-GOULART, M. T.; ANGHINAH, R.; AREZAFEGYVERES, R.; BAHIA, V. S.; DAMIN, A. E.; FORMIGONI, A. P.; FROTA, N. A. F; GUARIGLIA, C.; JACINTO, A. F.; KATO, E. M.; LIMA, E. E. P; MOREIRA, D.; NÓBREGA, A. B; PORTO, C. S.; MIRNA LIE HOSOGI SENAHA, M. L.; SILVA, M. N. M.; TALARICO, J. N. S.; RADANOVIC, M.; MANSUR, L. L. Influence of age, gender and educational level on performance in the Brief Cognitive Battery-Edu. Dementia $\&$ Neuropsychologia, v. 2, n. 2, p. 114-118, 2008.

OVASKAINEN, H.; UUSITALO, J.; VÄÄTÄINEN, K. Characteristics and significance of a harvester operators' working technique in thinnings. International Journal of Forest Engineering, v. 15, n. 2, p. 36-41 2004.

PAGNUSSAT, M. B.; LOPES, E. S. The behavioral profile of harvester operators. Revista Árvore, v. 41, n. 2, p. 1-7, 2017.

PURFÜRST, F. T. Learning curves of harvester operators. Croatian Journal of Forest Engineering, v. 3, n. 2, p. 89-97, 2010.

SEIDLER, R. D.; BERNARD, J. A.; BURUTOLU, T. B.; FLING, B. W.; GORDON, M. T.; GWIN, J. T.; KWAK, Y.; LIPPS, D. B. Motor control and aging: links to age-related brain structural, functional, and biochemical effects. Neuroscience \& Biobehavioral Reviews, v. 34, n. 5, p. 721-733, 2010.

SILAYO, A. S.; MINGUNGA, G. A.; SHEMWETTA, T. K.; Determination of learning curves and forgetting factors of two-man crosscut saw operators during tree cutting operations in a 'learn by doing' experiment. American Journal of Environmental Engineering, v. 5, n. 4, p. 106-116, 2014. 